\title{
An Experiment in Cooperation: The Colorado Program of Studies on Joint Action
}

S OME THREe YeARS AGo, in spite of war $\mathcal{S}$ and other difficulties, Colorado college librarians embarked upon a major project. They knew the difficulties ahead and realized that the program was beyond their own power to carry through alone. Yet what they were attempting was one of the most simple things imaginable: they wanted to see if by working together they could improve the library service.

The general situation has been well set forth by Dr. Ellsworth, ${ }^{1}$ who showed that Colorado has several state institutions of higher education with varying curricula, but with a certain duplication of subjects, all of which are treated from different points of view. The difficulty is that in spite of this difference of emphasis and degree of specialization, there is, and must be, a considerable overlapping in the collections of books and periodicals necessary for each institution, particularly in the case of materials used by undergraduate or lower division students or in certain basic sciences common to a number of subjects. In addition, there are several endowed colleges and universities and the Denver Public Library, all with their own programs which add to the complexities of the situation. The total amount spent for library service by the various colleges, when considered as a single

1 Ellsworth, Ralph E. "Activities of the Colorado Conference of Librarians of Institutions of Higher Learning." College and Research Libraries 4:233-38, 244, June r 943 . unit, is quite considerable, while the total book collections of all the institutions would make a respectable university library. However, the colleges are not centralized or properly coordinated, and the showing of any individual school is not notable.

Several years ago Malcolm G. Wyer saw the need for unity of action, and the Bibliographical Center for Research-Rocky Mountain Region was one of the results. The Colorado College and Head Librarians Conference (a cumbersome title for the rather informal gathering of librarians of institutions which are members of the bibliographical center), after a discussion of a number of the problems involved, elected by ballot a Special Committee for Centralized Technical Processes and Bookbuying to make recommendations as to the best ways of studying the situation. The committee decided that it was entering a field where there was very little precise knowledge, and therefore outlined at great length not only the wide range of studies which would have to be made but the complexity of their interrelationships. In addition, it set forth a number of other considerations that needed to be taken into account. ${ }^{2}$

As an indication of the factors included,

2 Colorado College and Head Librarians Conference. Special Committee on Centralized Technical Processes and Bookbuying. "First Report." [Fort Collins, Colorado State College Library, 1942.] 51p. Mimeographed. "Planning Studies on Centralization." [Fort Collins, Colorado State College Library, 1942.] $13 \mathrm{p}$. Mimeographed. 
here are some of the problems on which the committee felt that it did not have adequate data and that studies had to be made:

r. The actual cost of interlibrary loans as compared with purchasing, cataloging, and storing any particular title or volume

2. The differences in cost between borrowing within the cooperating group and from outside libraries

3. The actual amount of duplication, and the extent to which it could be avoided by a cheap, speedy, and efficient system of interlibrary loans

4. The effect which any change in technical processes would have upon the reference services of the various libraries

5. The comparative costs of storage in regular stacks, in storage warehouses on individual campuses, or in a central warehouse for all of the colleges

6. Practically every question that could be asked about any of the specific technical processes, either in the individual libraries or under any system of joint action.

Yet in spite of the "wilderness of ignorance" which it seemed to face, plus a fairly well-founded conviction that centralization for its own sake was definitely undesirable, the committee felt that some form of joint action might solve many of the problems that the libraries faced and recognized that some of the by-products of centralization might make that even more desirable.

The committee was aware that any single group, such as the one in Colorado, would get nowhere if it attempted to do all of the work itself, but thought that any progress on programs of joint action could come only from compact local regions, no matter whether the resultant programs proved to be of national utility or only of local promise. The members believed that any attempt to do anything "different" on a national scale would be blocked by the very size of the problems approached and by the enormous inertia of long-used local practices. Hence, it was felt that any program to be helpful, would have to be worked out first on a restricted regional basis.
At the same time the committee supposed there were other local groups in the United States with problems similar in nature to those faced in Colorado and that studies of problems and solutions for those regions would be useful to the libraries of Colorado. Again, certain questions that arose were obviously ones that could be answered if the committee knew enough about the internal workings, in terms both of cost and effectiveness, of a number of the large well-centralized and well-administered university libraries having a number of adequate departmental libraries. Obviously the problem then had simplified itself into just this: if the Colorado librarians were to get anywhere on their own program it could be done only if some interest could be aroused in other local groups and some degree of correlation secured for the proposed studies.

Under the leadership of the Colorado special committee a meeting was called in Chicago in February 1943, which resulted in the creation of the Joint Committee for the Study of Basic Problems in Technical Processes, whose function was to serve as an advisory clearinghouse for any studies which might be done either in Colorado or in other places. $^{3}$ Having completed its task, the Colorado special committee in its last report suggested the election by the Colorado group of a local Special Committee on Studying the Technical Processes, to promote studies feasible in Colorado.

The activities of this new Colorado committee have been restricted by three factors which had more influence than was expected when the investigations were first planned. In the first place, the three studies, which it had been confidently expected would be undertaken in Colorado during the school year 1943-44, were postponed. In

3 Colorado College and Head Librarians Conference. Special Committee on Centralized Technical Processes and Bookbuying. "Second Report." [Fort Collins, Colorado State College Library, 1943.] 14p. Mimeographed. 
the second place, the writer, who has been active in promoting the project, took a year's leave of absence to study some phases of rural reading at the Graduate Library School of the University of Chicago. Finally, Ralph E. Ellsworth left the directorship of the University of Colorado Libraries for that of the State University of Iowa, and the movement suffered a loss of that stimulation of interest which arose from certain fundamental differences of opinion within the group. ${ }^{4}$

In spite of these setbacks, it is still possible to show some progress for the Colorado project. Although the study of duplication in course offerings in the various institutions, as a basis for library programs, was not carried to completion, the preliminary drafts which were circulated among the librarians gave a fairly accurate understanding of the whole picture. The bibliographical center was able to compile a list of current periodicals received by various libraries in Colorado and Wyoming, ${ }^{5}$ which the writer analyzed as supplementary illustrative material to go with the survey of course offerings. ${ }^{6}$ The study of the periodical holdings showed that the sixteen libraries listed currently took 3475 different titles for 8208 sets, an average of nearly 2.4 holdings per title. ${ }^{7}$ Titles held by but one library (and so-called "uniques") accounted for exactly 50 per cent of the total number recorded, while those held by two libraries ("doubles") amounted to somewhat less than a fourth

\footnotetext{
Outline in Ellsworth, op. cit.

5 Bibliographical Center for Research, Rocky Mountain Region. "Union List of Periodicals Currently Received in the College and University Libraries of Colorado, and Wyoming. (Denver Public Library Included)." Boulder, University of Colorado Libraries, October 1942. 126p. Mimeographed.

- The results of this study are largely in manuscript form although certain of the data of local interest were mimeographed for the use of the faculty and the Advisory Library Committee of Colorado State College and copies were sent to other libraries in Colorado. Although not available for general distribution, the reference is: Hodgson, James G. "Periodical Subscriptions in Colorado and Wyoming. ." Fort Collins [Colorado State College Library]; May 1943. 31p. Mimeographed.

${ }^{7}$ More titles than this were given in the list but all serials that did not meet the definition of a periodical were disregarded.
}

more, leaving the titles held by three libraries or more ("triples plus") to come to slightly more than one quarter of the total number. Duplication among the "triples plus" was heavy, for the average number of libraries taking such titles was 5.04 .

In general the same situation held for the basic subjects. Here the percentage of "unique" titles ranged from 40.3 for the. general group to 57.2 for the humanities. Such a large percentage of titles held by a single library indicates not only that cooperation is necessary to make the best use of those titles by the colleges which overiap in subject interests but it also raises the question as to whether the percentage of "unique" titles is as high as it should be for the most efficient work of advanced students.

Location of copies by institution or by community is the next most important consideration. Table I shows that while the University of Colorado has on its Boulder campus the largest single collection of periodicals, the largest group on a community basis is found in Denver, in spite of the fact that the list did not include a great many specialized libraries from Denver with holdings of interest to the colleges. The figures given can be interpreted in a number of different ways, particularly in connection with the use of specific libraries. Mainly they show that if the greatest use is to be made of available resources the libraries must work together. They also indicate that no one library or community dominates the group. Thus even though the University of Colorado Library, at Boulder, secures 48.4 per cent of the actual titles, only 15.8 per cent of the total number are to be found in Boulder alone. At the same time the university would have to go outside the city to get 5 I.6 per cent of the items listed. If all Denver libraries are considered as a unit, they hold only 18.3 of the unique titles between them, and they 
TABLE I

Duplication of Periodical Titles by Libraries and

by Communities

\begin{tabular}{|c|c|c|c|c|c|}
\hline $\begin{array}{l}\text { Library or } \\
\text { Community }\end{array}$ & Uniques & Doubles & $\begin{array}{l}\text { Total } \\
\text { Titles }\end{array}$ & $\begin{array}{l}\text { Per Cent of } \\
\text { Grand Total }\end{array}$ & $\begin{array}{l}\text { Total } \\
\text { Sets }\end{array}$ \\
\hline University of Colorado & 549 & 349 & I680 & 48.4 & \\
\hline Denver Public & 205 & 234 & 1016 & $29 \cdot 3$ & \\
\hline Colorado State (A. \& M.) & 196 & 116 & 817 & 23.5 & \\
\hline University of Wyoming & 123 & 150 & 793 & 22.8 & \\
\hline University of Denver & $12 \mathrm{I}$ & I 8 & 786 & 22.6 & \\
\hline Colorado College & 36 & 71 & 623 & 17.9 & \\
\hline Colorado Mines & 129 & 123 & 550 & 15.8 & \\
\hline Greeley State & $4 \mathrm{I}$ & 50 & 457 & $13 \cdot 3$ & \\
\hline \multicolumn{6}{|l|}{ University of Colorado } \\
\hline School of Medicine & 135 & 139 & 398 & 11.4 & \\
\hline Grand Total* & I 733 & 758 & 3475 & & 8208 \\
\hline Denver & 635 & $630^{* *}$ & & & $2687^{* *}$ \\
\hline Boulder & 549 & 349 & & & 1680 \\
\hline Fort Collins & 196 & I $18 * *$ & & & $85 \mathrm{I} * *$ \\
\hline Laramie & 123 & 150 & & & 793 \\
\hline Colorado Springs & 36 & 71 & & & 623 \\
\hline Golden & I 29 & 123 & & & 550 \\
\hline Greeley & $4 \mathrm{I}$ & 50 & & & 457 \\
\hline
\end{tabular}

* Seven individual libraries not listed separately, and three not included in allocations by communities.

** Duplications not excluded where more than one library is recorded for a community.

need to go outside of the city to have access to perhaps 30 per cent of the pieces listed.

Such total figures have a value in themselves, but their real significance is more apparent when the scholarly value of the individual titles is concerned. Scholarly value in this case is a little hard to define. Obviously, it includes the items that are useful only for research purposes, a category which includes most foreign language titles. It probably includes most of the pieces that are useful for advance work (by upper division students and for specialized study), but it must not be forgotten that it also includes rather complete files of popular publications in some special fields, particularly in the social sciences, when the number of them makes it possible to undertake specific pieces of research. Two examples will suffice to illustrate the problem. ${ }^{8}$

Several of the schools offer some work in civil engineering. Considering only the titles which would be classed under that broad heading (eliminating those that are more general in character or those that deal with some of the specific fields such as highways, hydraulics, or irrigation) it was found (see Table II) that of the seventeen titles taken, seven or $4 \mathrm{I} .2$ per cent, were unique, while four were doubles and six were held by three or more libraries and accounted for twenty-one of the thirty-six sets recorded. More significant, only two of the titles were classified as essential for research purposes (both were in the French

8 Similar data was worked out for all of the subjects into which the study of course offering was divided, and the manuscript summary data has been made available to several of the librarians for their own use. 
language and both unique), although eight titles (representing twenty-two sets) were of an advanced nature. Here the figures indicate that cooperation is needed to increase the number of titles of a more scholarly or research character. They also point out an interesting fact-a small percentage of unique titles per library may easily result in a fairly high percentage for the region as a whole. titles were held by only one library and twenty-six by two libraries, leaving fortysix held by three or more libraries. It should be noted that one title was owned by twelve libraries, two in eleven cases, and five in nine. Since more advanced work is done in the fields of education than in civil engineering, the absence of foreign titles from the holdings is noticeable. The limited use that would be made of such titles

TABLE II

Holdings in Civil Engineering

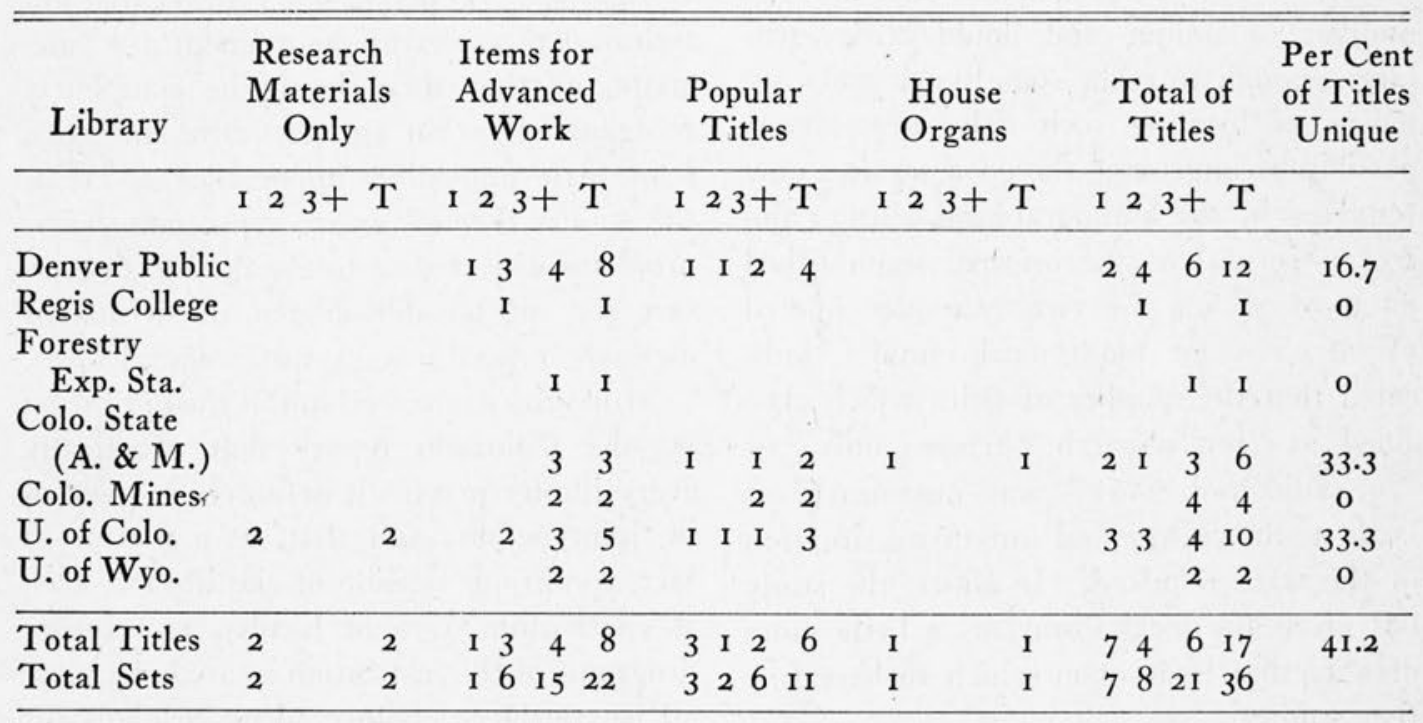

$1=$ Unique Titles-Held by one library only.

$2=$ Doubles Titles-Held by two libraries.

$3+=$ Triples plus-Held by three or more libraries. $\mathrm{T}=$ Total.

Nearly all of the schools offer some work in education and hence need some general titles in that field, in spite of the fact that in a number of instances the type of work given for a major is highly specialized. The data for the general periodical titles in the field shows only two in a foreign language (both Spanish) and only five others which come from outside the United States. Yet IOI titles, practically all of which could be classified only as "popular," were held by thirteen ${ }^{9}$ different libraries. Twenty-nine

${ }^{9}$ The original list did not include the professional library of the Denver Public Schools which has a great many titles not found in other libraries in the area.

in any one institution indicates that this is a desirable field for cooperative acquisition.

The examples given are typical only in that they are subjects on which there is a considerable lower division duplication, although their choice for this article was made more or less at random. Examples where specific schools were outstanding were many. For example: Colorado School of Mines in mining, mineralogy, and ceramics; Wyoming in wool; Colorado State in agronomy, irrigation, and veterinary medicine; and Colorado in labor relations.

Yet when it is remembered that periodical 
literature in geology, physics, and chemistry is essential for soil science and that background data for both mining and paleontology are often treated between the same covers, it may be understood that both the specific subjects and the general background must be considered in any study of duplication of titles and the availability of material.

The study as a whole did not demonstrate that duplication was greater than necessary but it did three things: ( $\mathrm{I}$ ) it showed that duplication was extensive enough to warrant careful study; (2) it demonstrated that the number of unique and double titles was large enough to make some quick and easy means of locating such titles necessarypossibly by improving the good services now rendered by the bibliographical center; and (3) a perusal of the original unpublished data, of which the two examples quoted above were not too typical samples, indicated that the number of titles which classified as "for research purposes only" or "for advanced work" was not nearly as large as the college and university situation of the state required. In short, the study has given the local librarians a little more of a factual basis upon which to base further studies.

Activities of the Joint Committee for the Study of Basic Problems in Technical Processes have naturally been limited. Failure of the proposed studies in Colorado to develop these last two years has not made it necessary to use the joint committee for consultative purposes, and it should not be expected that other area groups will be encouraged to make studies of their own or make use of the joint committee until more projects are brought to a head in
Colorado. Several studies, based upon the problems as outlined in the Colorado committee's reports, already have been undertaken in library schools.

Even though progress on the Colorado project has been slow, it still may be conceded that it is of fundamental significance. In the first place, it has divided the problem which must be investigated into specific and workable parts, in such a way that the conclusions reached in specific studies may be compared with the results from other investigations. Whether one believes that our technical processes of the moment are adequate, or that they should be completely reorganized on an entirely different basis, is of little immediate importance as far as the studies themselves are concerned. The problems were set up to get the facts necessary for any possible degree of revision of methods, procedures, or fundamental ideas.

More important, perhaps, is the indication by the Colorado report that practically every library process is definitely influenced by joint action; and that, as a matter of fact, conditions outside of the library, such as curriculum, type of faculty, and future programs of the institution as a whole, must all be considered before adequate plans for joint action can be made.

Finally, the scheme makes it possible for a great many different persons, active in different localities, to work on a coordinated program. The possibilities of cooperation are unlimited, since any person interested in any phase of the outline can obtain advice of the members of the joint committee by writing to either the chairman, $\mathrm{W}_{\text {yllis }}$ E. Wright, of the Army Medical Library, or the secretary, James G. Hodgson. 